\title{
Experimental inoculation of oriental river prawn Macrobrachium nipponense with white spot syndrome virus (WSSV)
}

\author{
Caiyuan Zhao', Hongtuo Fu ${ }^{1,2, *}$, Shengming Sun ${ }^{2}$, Hui Qiao ${ }^{2}$, Wenyi Zhang ${ }^{2}$, \\ Shubo Jin ${ }^{2}$, Sufei Jiang ${ }^{2}$, Yiwei Xiong ${ }^{2}$, Yongsheng Gong ${ }^{2}$ \\ ${ }^{1}$ Wuxi Fisheries College, Nanjing Agricultural University, Wuxi 214081, China \\ ${ }^{2}$ Key Laboratory of Freshwater Fisheries and Germplasm Resources Utilization, Ministry of Agriculture, \\ Freshwater Fisheries Research Center, Chinese Academy of Fishery Sciences, Wuxi 214081, China
}

\begin{abstract}
The oriental river prawn Macrobrachium nipponense is an economically important species that is widely farmed in China. White spot syndrome virus (WSSV) is one of the most devastating pathogens of the cultured shrimp Litopenaeus vannamei, responsible for massive loss of its commercial products worldwide. We investigated the infectivity and pathogenicity of WSSV in adult $M$. nipponense using standardized conditions for $L$. vannamei. The median lethal dose of WSSV in adult $M$. nipponense was $10^{3.84 \pm 0.06}$ copies $^{-1}$, which was about 1000 -fold higher than in L. vannamei $\left(10^{0.59 \pm 0.22}\right.$ copies $\left.\mathrm{g}^{-1}\right)$. WSSV was detected by 2 -step PCR in the gills, hepatopancreas, muscle, stomach, heart, gut, nerve, integument, pereopod, eyestalk, testis, and ovary of experimentally infected dead $M$. nipponense. Lesions were observed histologically following WSSV injection, showing basophilic intranuclear inclusion bodies in the hepatopancreas and subsequently in the gills. The clearance of WSSV was observed in hepatopancreas and gills at 48 and $96 \mathrm{~h}$ post-inoculation, respectively. No histological lesions were detected in muscle from 0-96 h post-injection. The results show that the oriental river prawn $M$. nipponense can be infected by WSSV and the infections are self limiting over time; therefore, $M$. nipponense may serve as a useful model for studying resistance to WSSV.
\end{abstract}

KEY WORDS: Nimaviridae $\cdot$ Whispovirus $\cdot$ Crustacean $\cdot$ LD $_{50} \cdot$ Histopathology Resale or republication not permitted without written consent of the publisher

\section{INTRODUCTION}

White spot syndrome virus (WSSV) is a virus in the genus Whispovirus, family Nimaviridae (Mayo 2002). WSSV infects a wide spectrum of crustaceans and is highly pathogenic to the farmed shrimp Litopenaeus vannamei, where it is responsible for major economic losses (Walker \& Mohan 2009, Corteel et al. 2012, Shi et al. 2012, Yuan et al. 2016). WSSV was first recorded in Taiwan in 1992 and subsequently observed worldwide (Chou et al. 1995, Pradeep et al. 2012). Losses due to WSSV are reported every year, and have been estimated at more US\$8 billion since 2000 (Bondad-Reantaso et al. 2001, Rosenberry 2001,
APHIS-USDA 2005, Dieu et al. 2004, Marks 2005, OIE 2011, Tendencia \& Verreth 2011, Tang et al. 2012, World Bank 2013). WSSV outbreaks occur continuously in China and exist widely in the wild (Jang et al. 2009, Ding et al. 2015, Li et al. 2016). The oriental river prawn Macrobrachium nipponense can be infected by WSSV via oral administration and intramuscular injection (Yun et al. 2014). In freshwater ponds, M. nipponense usually cohabitates with the Chinese mitten crab Eriocheir sinensis, and serious outbreaks of WSSV have caused catastrophic losses in harvests of E. sinensis (Ding et al. 2015). Red swamp crayfish Procambarus clarkii is usually used as a model organism for WSSV infection for research 
on the invertebrate innate immune system (Du et al. 2016). The Chinese mitten crab E. sinensis and the red swamp crayfish $P$. clarkii are both important WSSV carriers, and there is expanding literature on infection research for these species (Du et al. 2008, Zeng \& Lu 2009, Du et al. 2010, Bateman et al. 2012, Ding et al. $2017 \mathrm{a}, \mathrm{b})$. In the wild, E. sinensis and $P$. clarkii were more likely to carry WSSV than $M$. nipponense, and the natural prevalence level of $M$. nipponense was about $8.3 \%$ (Yin et al. 2017). The virus is transmitted horizontally to $E$. sinensis and $P$. clarkia (Yan et al. 2007) and the infection dynamics in these hosts is well known (Zeng \& Lu 2009, Zeng et al. 2011, Huang et al. 2015, Ding et al. 2017b). WSSV infectivity studies have been conducted on $M$. nipponense (Yun et al. 2014, Yin et al. 2017) but little is known about the infection dynamics in this host.

M. nipponense is an important economic species that is farmed widely in China (Ma et al. 2011, Fu et al. 2012, Yuan et al. 2015), with annual yields exceeding 265061 metric tonnes (Bureau of Fishery, Ministry of Agriculture 2016). Compared with penaeid shrimps, M. nipponense is generally considered to be less prone to disease in culture. Although there has been no outbreak caused by WSSV in farmed $M$. nipponense to date, it may serve as a reservoir for WSS and thus poses a potential threat to cultured L. vannamei.

WSSV can be diagnosed by PCR and histopathology (Sahul Hameed et al. 2003, Mijangos-Alquisires et al. 2006). Histological examination of WSSV-challenged $M$. nipponense may show visual changes in the target tissues. The gills play a vital role in transporting respiratory gases and controlling the osmotic and ionic balances in aquatic organisms, and WSSV causes histopathologically detectable changes in the gills of L. vannamei, Macrobrachium rosenbergii, Panulirus homarus, Penaeus indicus, Penaeus monodon, Panulirus orantus, and Scylla serrata (Rajendran et al. 1999, Yoganandhan et al. 2003, Syed Musthaq et al. 2006, Naresh et al. 2017). In addition, hepatopancreas is the main immune organ in shrimp (Jiang et al. 2014) and the center for storage, metabolism, and detoxification (Bhavan \& Geraldine 2009). Many viruses cause histopathologically detectable changes in the epithelium of hepatopancreas of the cultured crustaceans, including L. vannamei, Fenneropenaeus chinensis, Marsupenaeus japonicus, P. monodon, and Macrobrachium rosenbergii (Bateman \& Stentiford 2017, Zhang et al. 2017). However, information on histological changes following infection of WSSV in $M$. nipponense is lacking.
Before studying histological changes following infection of WSSV in $M$. nipponense, the pathogenicity of WSSV to $M$. nipponense should be studied first. One means to examine pathogenicity is to establish the median lethal dose $\left(\mathrm{LD}_{50}\right)$ of a pathogen or contaminant. The $\mathrm{LD}_{50}$ has been adopted extensively to evaluate the toxicity of WSSV in various marine and freshwater crustaceans (Escobedo-Bonilla et al. 2005, Du et al. 2006, Liu et al. 2011, Corteel et al. 2012, Zhu \& Quan 2012, Pace et al. 2016). We determined the $\mathrm{LD}_{50}$ of WSSV and examined infection levels in tissues of experimentally infected $M$. nipponense by 2step PCR. We examined the interactions between $M$. nipponense and WSSV by isolating and quantifying viable WSSV copies from infected $L$. vannamei. We also examined the histopathological changes in different tissues at different times following infection. The results of the present study will expound the pathogensis of WSSV in $M$. nipponense and facilitate the further prevention and control of WSSV in crustaceans.

\section{MATERIALS AND METHODS}

\section{Maintenance of experimental animals}

Litopenaeus vannamei free of WSSV were taken from culture ponds in Wuxi, China. Macrobrachium nipponense were purchased from the Lake Tai region of China. L. vannamei (weight $5.65 \pm 1.93 \mathrm{~g}$ ) and $M$. nipponense (weight $4.76 \pm 1.54 \mathrm{~g}$ ) were maintained in a recirculating-water aquarium system filled with aerated freshwater $\left(25 \pm 1^{\circ} \mathrm{C}\right)$ and fed with paludina (freshwater snails with an operculum) twice a day. Animals were acclimated for $7 \mathrm{~d}$ prior to experimental treatments.

\section{Viral inoculum preparation and quantification}

WSSV-infected L. vannamei were obtained from the School of Life Science, Sun Yat-sen University, in 2015. These animals had been diagnosed as positive by 2-step PCR using primers from the World Organisation for Animal Health (OIE 2012). The infected samples were stored at $-80^{\circ} \mathrm{C}$. DNA was extracted from samples using a TaKaRa MiniBEST Universal Genomic DNA Extraction Kit from Takara Biotechnology. The primers used for 2-step PCR are shown in Table 1. A $1 \mu$ aliquot of DNA template solution was add to a PCR tube containing $100 \mu \mathrm{l}$ of reaction mixture (10 mM Tris- $\mathrm{HCl}, \mathrm{pH}$ 8.8, $50 \mathrm{mM} \mathrm{KCl}$, 
Table 1. Primer sequences used for WSSV 2-step PCR and quantitative real-time PCR
$1.5 \mathrm{mM} \mathrm{MgCl} 2,0.1 \%$ Triton X-100, $200 \mu \mathrm{M}$ of each dNTP, 100 pmol of each primer, 2 U of heat-stable DNA polymerase). PCR was carried out as follows: one cycle of $94^{\circ} \mathrm{C}$ for $4 \mathrm{~min}, 55^{\circ} \mathrm{C}$ for $1 \mathrm{~min}$, and $72^{\circ} \mathrm{C}$ for $2 \mathrm{~min}$, followed by 39 cycles of $94^{\circ} \mathrm{C}$ for $1 \mathrm{~min}$, $55^{\circ} \mathrm{C}$ for $1 \mathrm{~min}$, and $72^{\circ} \mathrm{C}$ for $2 \mathrm{~min}$, and a final $5 \mathrm{~min}$ extension at $72^{\circ} \mathrm{C}$. The WSSV-specific amplicon from this reaction was 1447 base pairs. To visualize the results of $\mathrm{PCR}, 10 \mu \mathrm{l} \mathrm{PCR}$ products were electrophoresed on $1 \%$ agarose gels containing ethidium bromide at a concentration of $0.5 \mu \mathrm{g} \mathrm{ml}^{-1}$.

Tissue samples from infected $L$. vannamei, except for the hepatopancreas, can be used to prepare a WSSV inoculum (Rajendran et al. 2005). We prepared purified WSSV by homogenizing gills from infected shrimp in phosphate-buffered saline, followed by centrifugation at $8000 \times g$ for $30 \mathrm{~min}$ at $4^{\circ} \mathrm{C}$, and then filtering the supernatant fluid through a $0.4 \mu \mathrm{m}$ filter using a vacuum filter apparatus (Sahul Hameed at al. 2000). The filtrate was stored at $-20^{\circ} \mathrm{C}$ for subsequent studies.

We determined the WSSV copy number in triplicate using quantitative real-time PCR (qPCR) with the primers Wq-F and Wq-R (Table 1). A $1.5 \mu \mathrm{l}$ DNA sample was added to $15 \mu$ reaction mixture containing $1 \mathrm{\mu l}$ each primer, and qPCR was performed as follows: $95^{\circ} \mathrm{C}$ for $30 \mathrm{~s}$, followed by 40 cycles at $95^{\circ} \mathrm{C}$ for $10 \mathrm{~s}$ and $60^{\circ} \mathrm{C}$ for $10 \mathrm{~s}$. Melting curve analysis was performed at the end of the qPCR reaction at $65-95^{\circ} \mathrm{C}$ (in $0.5^{\circ} \mathrm{C}$ increments) for $10 \mathrm{~s}$. The WSSV-specific amplicon using Wq-F and Wq-R was cloned into the vector pMD 19-T Simple (Takara) and sequenced to confirm the sequences. The obtained recombinant plasmid was then transformed into competent Escherichia coli (DH5 $\alpha$, TransGen Biotech) and cultured for $12 \mathrm{~h}$. The recombinant plasmid was extracted from the E. coli to detect its concentration using an Eppendorf 2000 spectrophotometer. The WSSV DNA copy number was calculated as described by Sun et al. (2013). A standard curve for quantifying WSSV DNA copy numbers was made using serially diluted solutions of the recombinant plasmid.

\section{Dilutions, inoculation, and WSSV infectivity}

After quantification, the concentration of WSSV inoculum was $10^{6.2}$ copies $\mathrm{g}^{-1}$. L. vannamei and $M$. nipponense were stocked in 361 aquaria (10 animals per aquarium). For each trial, 10 animals were injected intramuscularly with WSSV inoculum $(20 \mu \mathrm{l})$ at 10 -fold serial dilutions $\left(10^{0}-10^{-6}\right)$. Animals serving as negative controls were injected with the same volume of phosphate-buffered saline. Each treatment was performed in triplicate. The inoculum was injected at the junction between the 3rd and 4th abdominal segments. Dead and moribund animals in each treatment group were recorded at $24 \mathrm{~h}$ intervals and examined by 2-step PCR to ensure the accuracy of the $\mathrm{LD}_{50}$. The WSSV LD $\mathrm{L}_{50}$ was calculated using the Behrens-Kärber method (Kärber 1931).

\section{Distribution of WSSV in Macrobrachium nipponense}

Dead M. nipponense exposed to WSSV were collected and heart, gill, stomach, gut, hepatopancreas, nerve, integument, muscle, pereopod, eyestalk, testis, and ovary tissue samples were sampled for PCR processing. Each tissue was examined in triplicate. DNA was extracted from the samples using a TaKaRa MiniBEST Universal Genomic DNA Extraction Kit and prepared for 2-step PCR to detect the presence of WSSV.

\section{Histopathology}

Hepatopancreas, gill, and muscle tissues were collected for histopathology studies at $0,24,48,72$, and $96 \mathrm{~h}$ post-inoculation (hpi) with WSSV. At each time point, 3 individuals were selected randomly. The concentration of WSSV injected was $40 \%$ of the $\mathrm{LD}_{50}$ for $M$. nipponense. Gill, hepatopancreas, and muscle were removed from $M$. nipponense and immersed immediately in Davidson's fixative for $48 \mathrm{~h}$, and then transferred to $70 \%$ ethanol for subsequent paraffin histology. Tissues were sectioned at 5-6 $\mu \mathrm{m}$ and stained with hematoxylin and eosin. WSSV copy number in the hepatopancreas, gill, and muscle tissues of $M$. nipponense were quantified by qPCR as above at each time point. 


\section{RESULTS}

\section{$\mathrm{LD}_{50}$ of WSSV in Litopenaeus vannamei and Macrobrachium nipponense}

For each trial, 10 animals were injected with WSSV inoculum at $10^{0}-10^{-6}$ dilutions. Litopenaeus vannamei injected with $10^{0}, 10^{-1}, 10^{-2}, 10^{-3}, 10^{-4}$, and $10^{-5}$ dilutions began to show disease signs from $24 \mathrm{hpi}$, whereas those injected with $10^{-6}$ dilutions began to show disease signs from $48 \mathrm{hpi}$. The clinical signs of WSSV infection in $L$. vannamei included lethargy, reduced appetite, and reddish coloration of body and appendages. White spots were seen on several individuals. Changes in behavior patterns included reduced swimming activity and disorientation with swimming to one side. Deaths occurred from 24 to $144 \mathrm{hpi}$, and dead animals were subjected to bioassays. The $\mathrm{LD}_{50}$ determined from 3 replicate treatments of $L$. vannamei $\left(10^{0.51}, 10^{0.42}\right.$, and $10^{0.83} \mathrm{LD}_{50}$ copies $\mathrm{g}^{-1}$ ) was $10^{0.59 \pm 0.22}$ copies $^{-1}$ (Fig. 1).

Among Macrobrachium nipponense injected with serial dilutions of WSSV, animals injected with $10^{\circ}$ or $10^{-1}$ dilutions began to show disease signs after $48 \mathrm{hpi}$, and those injected with $10^{-2}$ began to show disease signs after $72 \mathrm{hpi}$. The clinical signs in $M$. nipponense included lethargy, reduced appetite, and reddish coloration of body and appendages, but no white spots in the epidermal tissues were observed. Changes in behavior included reduced swimming activity and disorientation with swimming to one side. Deaths occurred from 48-144 hpi and dead ani-

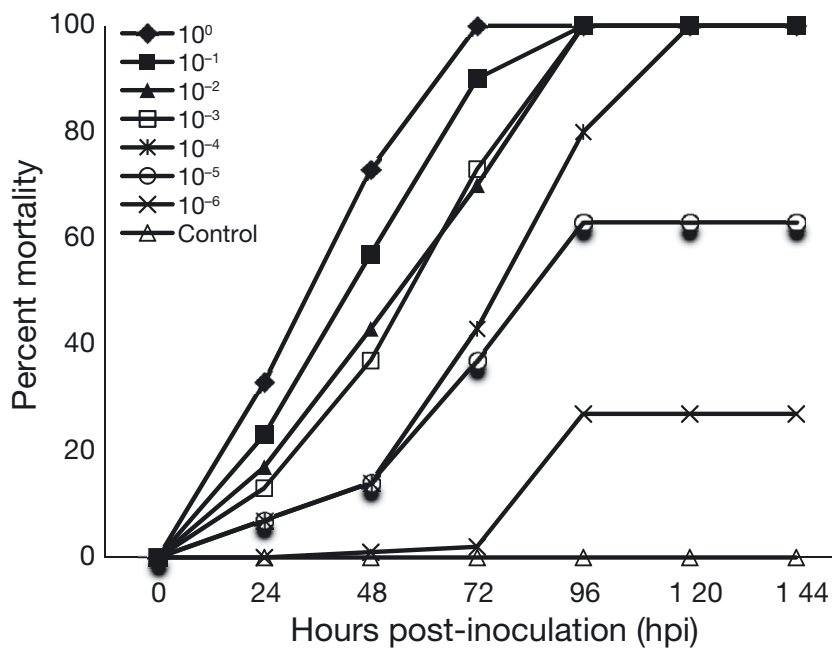

Fig. 1. Cumulative mortality for Litopenaeus vannamei injected with white spot syndrome virus and held over time. The viral dilution regime ranged from $10^{0}$ to $10^{-6}$. Data were from 3 replicates of $10 \mathrm{~L}$. vannamei individuals mals were bioassayed as above. The $\mathrm{LD}_{50}$ determined from the 3 replicate treatments of M. nipponense $\left(10^{3.91}, 10^{3.82}\right.$, and $10^{3.79} \mathrm{LD}_{50}$ copies $\left.\mathrm{g}^{-1}\right)$ was $10^{3.84 \pm 0.06}$ copies g $^{-1}$ (Fig. 2).

\section{Distribution of WSSV in M. nipponense}

WSSV was detected in the gills, hepatopancreas, muscle, stomach, heart, gut, nerve, epidermis, pereopod, eyestalk, testis, and ovary by simple PCR (Fig. 3). WSSV was detected as intranuclear inclusions in the epidermal cells of hepatopancreas and the hemocytes of gills by histological observation (Figs. 4B \& 5D). The WSSV copy number was significantly higher in the gills, hepatopancreas, and muscle compared with the other tissues, as assayed by simple PCR. The results of 3 replicates were the same.

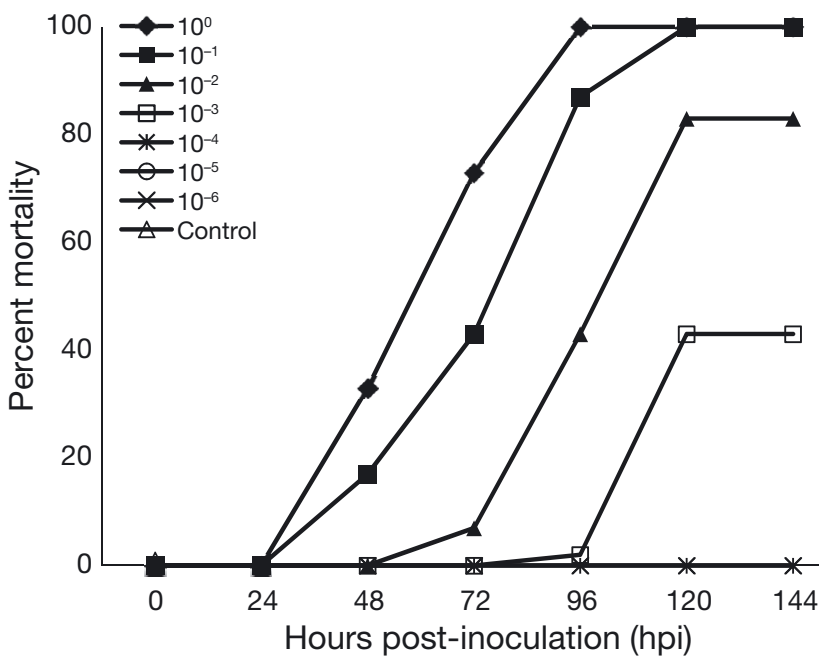

Fig. 2. Cumulative mortality for Macrobrachium nipponense injected with white spot syndrome virus and held over time. The viral dilution regime ranged from $10^{0}$ to $10^{-6}$. Data were from 3 replicates of $10 \mathrm{M}$. nipponense individuals

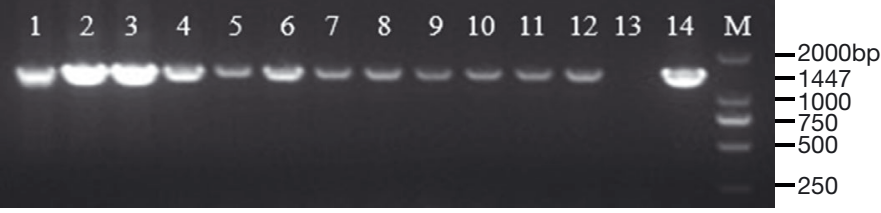

Fig. 3. Detection of white spot syndrome virus in different tissues of experimentally infected Macrobrachium nipponense by 1-step PCR. Lane 1: gill; lane 2: hepatopancreas; lane 3: muscle; lane 4: stomach; lane 5: heart; lane 6: gut; lane 7: nerve; lane 8: integument; lane 9: pereopod; lane 10: eyestalk; lane 11: testis; lane 12: ovary; lane 13: negative control; lane 14: positive control; lane M: marker 


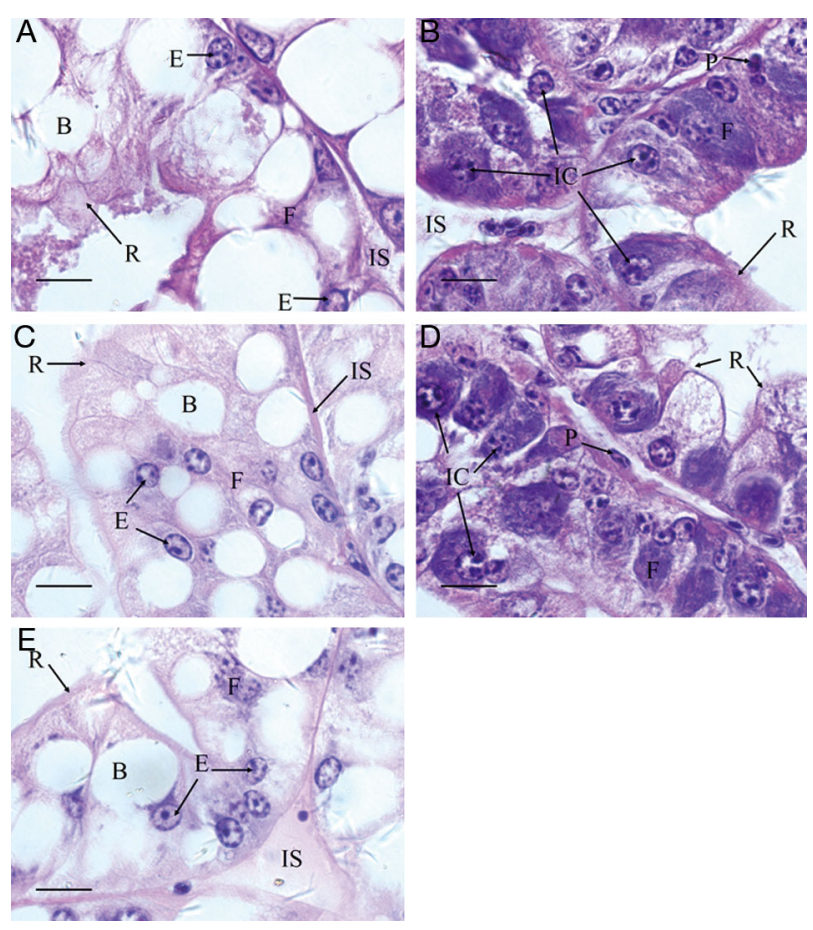

Fig. 4. (A) Hepatopancreas from Macrobrachium nipponense experimentally infected with white spot syndrome virus (WSSV) at $0 \mathrm{~h}$ post-inoculation (hpi). Typical organization of the hepatopancreas. E: embryonic cells. B: blasenzellen; R: restzellen; F: fibrillenzellen; IS: interstitial sinus. (B) Hepatopancreas from experimentally infected M. nipponense at $24 \mathrm{hpi}$. Presence of more R cells in the hepatopancreas tubules of infected prawns, basophilic intranuclear inclusion bodies (IC), and pyknosis (P). (C) Hepatopancreas from experimentally infected $M$. nipponense at $48 \mathrm{hpi}$. Hepatopancreas tubules showed clearance of WSSV and turn to typical organization. (D) Hepatopancreas from experimentally infected $M$. nipponense at 72 hpi showing basophilic IC. (E) Hepatopancreas from experimentally infected $M$. nipponense at 96 hpi. Presence of more Band R cells in the hepatopancreas tubules, decreased basophilic IC. All scale bars $=2 \mu \mathrm{m}$

\section{Histopathology}

Hepatopancreas from $M$. nipponense at 0 hpi showed a normal, well-organized glandular structure. The tubules were closed distally on one side and open proximally into ducts, which united to form longer ducts, ultimately connected to the digestive tract. Embryonic (E) cells were found at the narrow distal end of the tubule, some showing mitotic figures. Restzellen (R) cells, and non-vacuolated and deeply stained fibrillenzellen $(F)$ cells were found a short distance away from the distal region. Vacuolated blasenzellen (B) cells were found in the middle and proximal regions of the tubules. The interstitial sinuses between the
A

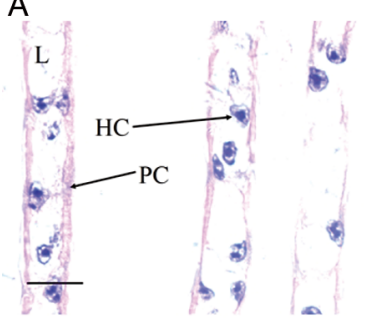

C
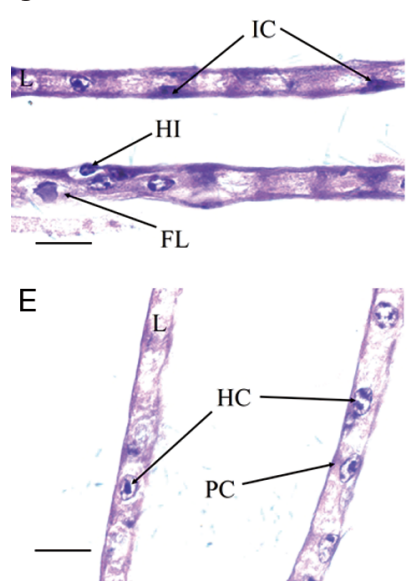

Fig. 5. (A) Gills from Macrobrachium nipponense experimentally infected with white spot syndrome virus (WSSV) at $0 \mathrm{~h}$ post-inoculation (hpi). Normal organization of the gills. L: lamellae; PC: pillar cells; HC: Hemocytes. (B) Gills from experimentally infected $M$. nipponense at 24 hpi. Normal organization of the gills. (C) Gills from experimentally infected M. nipponense at $48 \mathrm{hpi}$. Hemocytic infiltration (HI), fusion of gill lamellae (FL), and basophilic IC in infected prawns. (D) Gills from experimentally infected $M$. nipponense at $72 \mathrm{hpi}$. FL and basophilic IC in infected prawns. (E) Gills from experimentally infected $M$. nipponense at $96 \mathrm{hpi} \mathrm{showing} \mathrm{clear-}$ ance of WSSV and turn to normal gill organization. All scale bars $=2 \mu \mathrm{m}$

tubules were normal (Fig. 4A). The hepatopancreas of $M$. nipponense at $24 \mathrm{hpi}$ exhibited increased numbers of F and R cells compared with $0 \mathrm{~h}$ hpi, as well as enlarged nuclei with marginalized chromatin, and often contained a distinct basophilic inclusion body. Pyknotic nuclei were more abundant than at $0 \mathrm{hpi}$ and the size of the B cells was decreased (Fig. 4B). At 48 hpi, the hepatopancreas of $M$. nipponense exhibited a well-organized glandular structure again showing the clearance of WSSV and normal numbers of B, F, and R cells; the basophilic intranuclear inclusion bodies had decreased or even disappeared, and pyknotic nuclei were decreased (Fig. 4C). The hepatopancreas of M. nipponense at 72 hpi exhibited abundant basophilic intranuclear inclusion bodies again, and similar numbers of $\mathrm{F}$ and $\mathrm{R}$ cells to the hepatopancreas at 24 hpi. By 96 hpi, the hepatopancreas showed the 
clearance again (Fig. 4D), with decreased basophilic intranuclear inclusion bodies and increasing numbers of B and R cells (Fig. 4E). The WSSV concentration of hepatopancreas at $0,24,48,72$, and 96 hpi were 0 , $10^{3.9}, 10^{2.8}, 10^{3.5}$, and $10^{2.6}$ copies $\mathrm{g}^{-1}$. The clearance of WSSV in hepatopancreas came out together with the decrease in both WSSV concentration and number of basophilic inclusion bodies at 48 and $96 \mathrm{hpi}$, respectively.

The gills of $M$. nipponense at 0 hpi showed normal lamellae (L) and hemocoelic sinuses, with hemocytes $(\mathrm{HC})$ in the circulation and no structural abnormalities or abnormal gill lesions. Specialized epithelial cells, pillar cells (PC), stretched into the lamellar sinus at intervals and adjoined similar cells stretching from the opposite surface (Fig. 5A). At $24 \mathrm{hpi}$, the gills showed normal lamellae, similar to 0 hpi (Fig. 5B). However, by $48 \mathrm{hpi}$, the gills of $M$. nipponense showed hemocytic infiltration (HI) in the hemocoelic sinuses, fusion of lamellae (FL), and basophilic inclusion bodies (Fig. 5C). The number of basophilic inclusion bodies had increased by $72 \mathrm{hpi}$, showing severe pathology induced by WSSV (Fig. 5D). The gills cleared WSSV and turned to normal organization at 96 hpi together with the decreased WSSV concentration, showing a decreased number of basophilic inclusion bodies (Fig. 5E). The WSSV concentration of gills at $0,24,48,72$, and 96 hpi were $0,0,10^{3.0}, 10^{3.5}$, and $10^{2.7}$ copies $\mathrm{g}^{-1}$.

There were no discernible pathological changes in muscle cells, with apparently normal skeletal muscle and fiber cells from 0 to $96 \mathrm{hpi}$ and the WSSV concentration at each time point was also 0 copies $\mathrm{g}^{-1}$.

\section{DISCUSSION}

WSSV infects a broad range of crustaceans, including the shrimps Fenneropenaeus indicus (Bright Singh et al. 2005), Marsupenaeus japonicus (Satoh et al. 2008), and Penaeus monodon (Das et al. 2010), fresh water prawns Macrobrachium idella, Macrobrachium lamerrae (Sahul Hameed et al. 2000), and Macrobrachium rosenbergii (Rao et al. 2016), the crayfish Astacus, Pacifastacus leniusculus (Jiravanichpaisal et al. 2004), and Cherax quadricarinatus (Mrugała et al. 2015), and the crabs Calappa philargius, Paradorippe granulata, Scylla serrata, and Thalamita danae (Chen et al. 2000, Sahul Hameed et al. 2003). The susceptibility of a host to WSSV can be reflected in the copy numbers found during active infections (Sahul Hameed et al. 2003, MijangosAlquisires et al. 2006, Bateman et al. 2012), and the
$\mathrm{LD}_{50}$ is a common mean to examine its pathogenicity. The $\mathrm{LD}_{50}$ value of Litopenaeus vannamei to a Thai isolate of WSSV was $10^{6.6}$ copies $\mathrm{ml}^{-1}$ (EscobedoBonilla et al. 2005), that of $M$. rosenbergii to WSSVThai-1 and WSSV-Viet were $10^{5.4 \pm 0.4}$ and $10^{2.3 \pm 0.3}$ copies $\mathrm{ml}^{-1}$, respectively (Corteel et al. 2012), that of Procambarus clarkii to the native WSSV was $10^{1.3}-10^{3.3}$ copies $\mathrm{ml}^{-1}$ (Pace et al. 2016), and of S. serrata was $10^{5}$ copies $\mathrm{ml}^{-1}$ (Liu et al. 2011). In the present study, $M$. nipponense readily supported WSSV replication, leading to disease and mortality. The $\mathrm{LD}_{50}$ values of $L$. vannamei and $M$. nipponense to WSSV were $10^{0.59 \pm 0.22}$ and $10^{3.84 \pm 0.06}$ copies $\mathrm{g}^{-1}$, respectively, indicating an approximately 1000 -fold higher $\mathrm{LD}_{50}$ for $M$. nipponense compared with $L$. vannamei. Compared with $L$. vannamei, $M$. nipponense appeared to be more capable of resisting WSSV infection and disease, similar to the situation for WSSV-Thai-1 and WSSV-Viet in M. rosenbergii (Corteel et al. 2012). These data indicate that higher doses of WSSV are required to establish infection in the oriental river prawn $M$. nipponense.

The success of a viral infection (successful replication) depends mainly on the interactivity between the viral attachment proteins and the host's specific cellular receptors (Sánchez-Paz 2010). WSSV's ability to infect a broad range of crustaceans suggests that the virus interacts with a general cell surface receptor common to most crustaceans (Liang et al. 2005). WSSV can replicate in all the vital organs of infected penaeid shrimps (Syed Musthaq et al. 2006). However, WSSV cannot infect all types of cells indiscriminately. The main target tissues for WSSV infection are the epidermis, foregut, gills, antennal gland, hindgut, gonads, lymphoid organ, hematopoietic cells, cells associated with the nervous system, and connective tissue (Jiravanichpaisal et al. 2006, Reddy et al. 2010, Han et al. 2013, Söderhäll 2013, Li et al. 2014, Yan et al. 2016), whereas the other tissues, such as the hepatopancreas and gut, are refractory to WSSV infection (Sahul Hameed et al. 1998, Wang et al. 1997). WSSV was detected as intranuclear inclusions in eyestalk, gills, head soft tissue, connective tissue, appendages, and Y-organ by histopathological observations (Vijayan et al. 2003, Yoganandhan et al. 2003). However, WSSV was detected in the hepatopancreas in P. monodon and M. rosenbergii and in the gut of $M$. japonicus by in situ hybridization (Chang et al. 1996, Di Leonardo et al. 2005, Corteel et al. 2012). The hepatopancreas is involved in filtering out stuff from the hemolymph and that would include products of tissue damage; hence, the WSSV presented in these types of cells could be transited from 
other organs (Di Leonardo et al. 2005). Pleopods, gills, hemolymph, stomach, and abdominal muscle are the 5 most prevalent infected organs in shrimps (Lo et al. 1997, Jeswin et al. 2013), while the gills, heart, stomach, gut, hepatopancreas, nerve, epidermis, muscle, pereopod, eyestalk, testis, and ovary were shown to be WSSV-positive by 2-step PCR in the current study. These results were consistent with others for L. vannamei (Ashikaga et al. 2009).

The histological changes induced by WSSV have been widely investigated in shrimps. Histological studies of WSSV-infected shrimps showed degenerated cells, characterized by basophilic intranuclear inclusion bodies in hypertrophied nuclei of ectodermal and mesodermal origins (Sahul Hameed et al. 2002, Durand et al. 2003, Rodríguez et al. 2003, Tang et al. 2013).The present study revealed discernible cellular degeneration, nuclei hypertrophy with basophilic intranuclear bodies, and chromatin margination in the hepatopancreas and gill cells at 24 and 48 hpi, respectively. The hepatopancreas consists of branched tubules made up of 4 different types of epithelial cells (B, F, R, and E cells). The hepatopancreas functions of storage, metabolism, and detoxification are mediated by $\mathrm{R}$ cells (Li et al. 2007). WSSV infection of $M$. nipponense resulted in increased numbers of $\mathrm{F}$ and $\mathrm{R}$ cells in the hepatopancreas, accompanied by basophilic intranuclear Cowdry type-A inclusion bodies and decreased size of B cells. The WSSV concentration had the same fluctuation with the changes in histopathology following different infection times in the hepatopancreas of $M$. nipponense, suggesting that hepatopancreas at 48 and 96 hpi had an efficient resistance to WSSV. The increasing number of $\mathrm{R}$ cells in the hepatopancreas in WSSV-infected $M$. nipponense may be a stress response to the virus, be a defensive reaction to the virus or simply be a metabolic response to the disease in terms of mobilizing resources.

Histopathological changes in the gills of WSSVinfected $M$. nipponense were similar to those reported in L. vannamei (Rajendran et al. 2005, Afsharnasab et al. 2009, Pazir et al. 2011). The gills of $M$. nipponense showed hemocytic infiltration in the hemocoelic sinuses, fusion of lamellae, and basophilic inclusion bodies at $48 \mathrm{hpi}$. The basophilic inclusion bodies induced by WSSV observed in gills were the same as those reported by Yun et al. (2014). The reduction of viral load and mitigation histopathology of hepatopancreas and gills were indicated by the decreased number of basophilic inclusion bodies and WSSV concentration, and the increased number of B cells in hepatopancreas. The WSSV concentration had the same fluctuation as the changes in histopathology following different infection time in the gills of M. nipponense. Yoganandhan et al. (2003) recorded histopathological evidence of WSSV in gills of $P$. indicus at $36 \mathrm{hpi}$, whereas the hepatopancreas remained negative, even when shrimp were in a moribund state. Afsharnasab et al. (2009) found intranuclear Cowdry type-A inclusion bodies in all tissues except the hepatopancreas in $L$. vannamei. However, the hepatopancreas and gill cells in the current study showed signs of clearance of WSSV at 48 and 96 hpi, respectively. To the best of our knowledge, this is the first evidence for this phenomenon in crustaceans. The results of our study differed from those of Yoganandhan et al. (2003) and Afsharnasab et al. (2009) in that the hepatopancreas cells in $M$. nipponense were more likely to be damaged by WSSV than $L$. vannamei. Furthermore, the clearance of WSSV in the hepatopancreas and gills also suggested that $M$. nipponense was more able to resist WSSV infection than L. vannamei. The earlier histopathological signs of infection in the hepatopancreas suggests that the hepatopancreas is more likely to be affected by WSSV than the gills in $M$. nipponense.

The immune response of crustaceans to invading pathogens includes phagocytosis, encapsulation, and melanization. Encapsulated pathogens are often collected in the gills or hepatopancreas, where they are broken down and subsequently cleared (Hauton 2012). High tolerance and clearing mechanisms for WSSV have been reported in the giant freshwater prawn M. rosenbergii (Pais et al. 2007, Sarathi et al. 2008). WSSV-infected shrimp such as $F$. indicus show an efficient immune response to WSSV, but the compensation mechanism appears unable to maintain resistance against infection, suggesting that this shrimp cannot protect itself from WSSV infection (Sarathi et al. 2007). However, the clearance of WSSV in the hepatopancreas and gills of M. nipponense implies that it has an effective immune response with efficient healing compensation against WSSV.

Acknowledgements. This work was supported by the special items of basic research projects of Chinese Academy of Fishery Sciences (2016HY-ZD0402), the National Natural Science Foundation of China (Grant No. 31572617), the Science and Technology Supporting Program of Jiangsu Province (BE2016308), the Fund of Independent Innovation of Agricultural Sciences of Jiangsu province (CX (15)1012$4)$, the key project of provincial key research and development plan (Modern Agriculture) (BE2016308), the Three Aquatic Projects of Jiangsu Province (D2015-16), and the Science and Technology Development Fund of Wuxi (CLE02N1514). 


\section{LITERATURE CITED}

Afsharnasab M, Mortezaei R, Yegane V, Kazemi B (2009) Gross sign, histopathology and polymerase chain reaction observations of white spot syndrome virus in shrimp specific pathogen free Litopeneaus vannamei in Iran. Asian J Anim Vet Adv 4:297-305

APHIS-USDA (Animal and Plant Health Inspection Service-United States Department of Agriculture) (2005) Impact worksheet white spot disease in Brazil. APHIS-USDA, Natural Resources Research, Fort Collins, $\mathrm{CO}$

Ashikaga K, Kono T, Sonoda K (2009) The tissue distribution of white spot syndrome virus (WSSV) in experimentally infected kuruma shrimp (Marsupenaeus Japonicus) as assessed by quantitative real-time PCR. Aquacult Sci 57: 91-97

Bateman KS, Stentiford GD (2017) A taxonomic review of viruses infecting crustaceans with an emphasis on wild hosts. J Invertebr Pathol 147: 86-110

Bateman KS, Tew I, French C, Hicks RJ, Martin P, Munro J, Stentiford GD (2012) Susceptibility to infection and pathogenicity of white spot disease (WSD) in non-model crustacean host taxa from temperate regions. J Invertebr Pathol 110:340-351

Bhavan PS, Geraldine P (2009) Manifestation of carbaryl toxicity on soluble protein and histopathology in the hepatopancreas and gills of the prawn, Macrobrachium malcolmsonii. J Environ Biol 30:533-538

Bondad-Reantaso MG, Mcgladdery SE, East I, Subasinghe RP (2001) Asia diagnostic guide to aquatic animal diseases. FAO, Rome

Bright Singh IS, Manjusha M, Pai SS, Philip R (2005) Fenneropenaeus indicus is protected from white spot disease by oral administration of inactivated white spot syndrome virus. Dis Aquat Org 66:265-270

Bureau of Fishery, Ministry of Agriculture (2016) Fisheries economic statistics: China fishery yearbook. China Agricultural Press, Beijing

Chang PS, Lo CF, Wang YC, Kou GH (1996) Identification of white spot syndrome associated baculovirus (WSBV) target organs in the shrimp Penaeus monodon by in situ hybridization. Dis Aquat Org 27:131-139

Chen LL, Lo CF, Chiu YL, Chang CF, Kou GH (2000) Natural and experimental infection of white spot syndrome virus (WSSV) in benthic larvae of mud crab Scylla serrate. Dis Aquat Org 40:157-161

Chou HY, Huang CY, Wang CH, Chiang HC, Lo CF (1995) Pathogenicity of a baculovirus infection causing white spot syndrome in cultured penaeid shrimp in Taiwan. Dis Aquat Org 23:165-173

Corteel M, Dantas-Lima JJ, Tuan VV, Thuong KV and others (2012) Susceptibility of juvenile Macrobrachium rosenbergii to different doses of high and low virulence strains of white spot syndrome virus (WSSV). Dis Aquat Org 100:211-218

* Das R, Karthireddy S, Gireesh-Babu P, Reddy AK, Krishna G, Chaudhari A (2010) Protection of Penaeus monodon from infection of white spot syndrome virus, by DNA construct expressing long hairpin-RNA against ICP11 gene. Indian J Virol 21:95

*Di Leonardo VA, Bonnichon V, Roch P, Parrinello N, Bonami JR (2005) Comparative WSSV infection routes in shrimp genera Marsupenaeus and Palaemon. J Fish Dis 28: 565-569
Dieu BTM, Marks H, Siebenga JJ, Goldbach RW, Zuidema D, Duong TP, Vlak JM (2004) Molecular epidemiology of white spot syndrome virus within Vietnam. J Gen Virol 85:3607-3618

* Ding Z, Yao Y, Zhang F, Wan J, Sun M, Liu H (2015) The first detection of white spot syndrome virus in naturally infected cultured Chinese mitten crabs, Eriocheir sinensis in China. J Virol Methods 220:49-54

* Ding Z, Wang S, Zhu X, Pan J, Xue H (2017a) Temporal and spatial dynamics of white spot syndrome virus in the Chinese mitten crab, Eriocheir sinensis. Aquacult Res 48: 2528-2537

* Ding ZF, Cao MJ, Zhu XS, Xu GH, Wang RL (2017b) Changes in the gut microbiome of the Chinese mitten crab (Eriocheir sinensis) in response to white spot syndrome virus (WSSV) infection. J Fish Dis (in press)

* Du HH, Li WF, Xu ZR (2006) Effect of hyperthermia on the replication of white spot syndrome virus (WSSV) in Procambarus clarkii. Dis Aquat Org 71:175-178

* Du H, Wei D, Han X, Li W, Xu Y, Xu Z (2008) Effect of low water temperature on viral replication of white spot syndrome virus in Procambarus clarkii. Aquaculture 277: 149-151

Du ZQ, Li XC, Wang ZH, Zhao XF, Wang JX (2010) A single WAP domain (SWD)-containing protein with antipathogenic relevance in red swamp crayfish, Procambarus clarkii. Fish Shellfish Immunol 28:134-142

* Du Z, Jin Y, Ren D (2016) In-depth comparative transcriptome analysis of intestines of red swamp crayfish, Procambarus clarkii, infected with WSSV. Sci Rep 6:26780

* Durand SV, Redman RM, Mohney LL (2003) Qualitative and quantitative studies on the relative virus load of tails and heads of shrimp acutely infected with WSSV. Aquaculture 216:9-18

* Escobedo-Bonilla CM, Wille M, Sanz VA, Sorgeloos P, Pensaert MB, Nauwynck HJ (2005) In vivo titration of white spot syndrome virus (WSSV) in specific pathogen-free Litopenaeus vannamei by intramuscular and oral routes. Dis Aquat Org 66:163-170

Fu H, Jiang S, Xiong Y (2012) Current status and prospects of farming the giant river prawn (Macrobrachium rosenbergii) and the oriental river prawn (Macrobrachium nipponense) in China. Aquacult Res 43:993-998

*Han Q, Li P, Lu X, Guo Z, Guo H (2013) Improved primary cell culture and subculture of lymphoid organs of the greasyback shrimp Metapenaeus ensis. Aquaculture 410-411:101-113

Hauton C (2012) The scope of the crustacean immune system for disease control. J Invertebr Pathol 110:251-260

* Huang HT, Chan HL, Chen LL (2015) A study of the role of glucose transporter 1 (Glut1) in white spot syndrome virus (WSSV) infection. Fish Shellfish Immunol 46:305-314

* Jang IK, Meng XH, Seo HC, Cho YR, Kim BR, Ayyaru G, Kim JS (2009) A TaqMan real-time PCR assay for quantifying white spot syndrome virus (WSSV) infections in wild broodstock and hatchery-reared postlarvae of fleshy shrimp, Fenneropenaeus chinensis. Aquaculture 287:40-45

Jeswin J, Anju A, Thomas PC, Paulton MP, Vijayan KK (2013) Analysis of viral load between different tissues and rate of progression of white spot syndrome virus (WSSV) in Penaeus monodon. Aquacult Res 46: 2003-2012

* Jiang H, Li F, Zhang J, Zhang J, Huang B, Yu Y, Xiang J (2014) Comparison of protein expression profiles of the 
hepatopancreas in Fenneropenaeus chinensis challenged with heat-inactivated Vibrio anguillarum and white spot syndrome virus. Mar Biotechnol (NY) 16: 111-123

Jiravanichpaisal P, Söderhäll K, Söderhäll I (2004) Effect of water temperature on the immune response and infectivity pattern of white spot syndrome virus (WSSV) in freshwater crayfish. Fish Shellfish Immunol 17:265

* Jiravanichpaisal P, Söderhäll K, Söderhäll I (2006) Characterization of white spot syndrome virus replication in in vitro-cultured haematopoietic stem cells of freshwater crayfish, Pacifastacus leniusculus. J Gen Virol 87: 847-854

Kärber G (1931) Beitrag zur kollektiven Behandlung pharmakologischer Reihenversuche. Naunyn Schmiedebergs Arch Exp Pathol Pharmakol 162:480-483

Li N, Zhao Y, Yang J (2007) Impact of waterborne copper on the structure of gills and hepatopancreas and its impact on the content of metallothionein in juvenile giant freshwater prawn Macrobrachium rosenbergii (crustacea: decapoda). Arch Environ Contam Toxicol 52:73-79

* Li W, Nguyen VT, Corteel M, Dantas-Lima JJ, Van Thuong K, Van Tuan V, Nauwynck H (2014) Characterization of a primary cell culture from lymphoid organ of Litopenaeus vannamei and use for studies on WSSV replication. Aquaculture 433:157-163

* Li K, Liu L, Clausen JH, Lu M, Dalsgaard A (2016) Management measures to control diseases reported by tilapia (Oreochromis spp.) and whiteleg shrimp (Litopenaeus vannamei) farmers in Guangdong, China. Aquaculture 457:91-99

Liang Y, Huang J, Song XL, Zhang PJ, Xu HS (2005) Four viral proteins of white spot syndrome virus (WSSV) that attach to shrimp cell membranes. Dis Aquat Org 66: 81-85

Liu W, Qian D, Yan XJ (2011) Studies on pathogenicity and prevalence of white spot syndrome virus in mud crab, Scylla serrata (Forskal), in Zhejiang Province, China. J Fish Dis 34:131-138

Lo CF, Ho CH, Chen CH, Liu KF and others (1997) Detection and tissue tropism of white spot syndrome baculovirus (WSBV) in captured brooders of Penaeus monodon with a special emphasis on reproductive organs. Dis Aquat Org 30:53-72

Ma K, Jianbin F, Jingyun L (2011) The complete mitochondrial genome of Macrobrachium nipponense. Gene 487: 160-165

Marks H (2005) Genomics and transcriptomics of white spot syndrome virus. PhD dissertation, Wageningen University

Mayo MA (2002) A summary of taxonomic changes recently approved by ICTV. Arch Virol 147:1655-1656

*Mijangos-Alquisires Z, Quintero-Arredondo N, Castro-Longoria R, Grijalva-Chon JM, Ramos-Paredes J (2006) White spot syndrome virus (WSSV) in Litopenaeus vannamei captured from the Gulf of California near an area of extensive aquaculture activity. Dis Aquat Org 71:87

Mrugała A, Kozubíková-Balcarová E, Chucholl C, Cabanillas RS, Viljamaa-Dirks S, Vuki J, Petrusek A (2015) Trade of ornamental crayfish in Europe as a possible introduction pathway for important crustacean diseases: crayfish plague and white spot syndrome. Biol Invasions $17: 1313$

Naresh KD, Ayyaru G, Kuzhanthaivel R, Somasundaram TS, Gary GM, Daniel K, Ramakrishna RS (2017) Incidence of simultaneous infection of infectious hypodermal and haematopoietic necrosis virus (IHHNV) and white spot syndrome virus (WSSV) in Litopenaeus vannamei. Aquaculture 471:1-7

OIE (World Organisation for Animal Health) (2011) Immediate notification, submitted date: 04/10/2011. Office International des Epizooties, Paris

OIE (World Organisation for Animal Health) (2012) Manual of diagnostic tests for aquatic animals 2012. OIE-World Organisation for Animal Health, Paris

* Pace BT, Hawke JP, Subramanian R, Green CC (2016) Experimental inoculation of Louisiana red swamp crayfish Procambarus clarkii with white spot syndrome virus (WSSV). Dis Aquat Org 120:143-150

*Pais R, Shekar M, Karunasagar I, Karunasagar I (2007) Hemagglutinating activity and electrophoretic pattern of hemolymph serum proteins of Penaeus monodon and Macrobrachium rosenbergii to white spot syndrome virus injections. Aquaculture 270:529-534

Pazir MK, Afsharnasab M, Jafari BJ, Sharifpour I, Motalebi AA, Dashtiannasab A (2011) Detection and identification of white spot syndrome virus (WSSV) and infectious hypodermal and hematopoietic necrosis virus (IHHNV) of Litopenaus vannamei from Bushehr and Sistan and Baloochestan provinces (Iran), during 2009-2010. Iran J Fish Sci 10:708-726

* Pradeep B, Rai P, Mohan SA, Shekhar MS, Karunasagar I (2012) Biology, host range, pathogenesis and diagnosis of white spot syndrome virus. Indian J Virol 23:161-174

* Rajendran KV, Vijayan KK, Santiago TC, Krol RM (1999) Experimental host range and histopathology of white spot syndrome virus (WSSV) infection in shrimp, prawns, crabs and lobsters from India. J Fish Dis 22:183-191

* Rajendran KV, Vijayan KK, Santiago TC, JJS R (2005) White spot syndrome virus (WSSV) infection in tiger shrimp Penaeus monodon: a non-lethal histopathological rapid diagnostic method using paraffin and frozen sections. Aquacult Int 13:341-349

* Rao R, Bhassu S, Bing RZ, Alinejad T, Hassan SS, Wang J (2016) A transcriptome study on Macrobrachium rosenbergii hepatopancreas experimentally challenged with white spot syndrome virus (WSSV). J Invertebr Pathol 136:10-22

Reddy AD, Jeyasekaran G, Shakila RJ (2010) Incidence of white spot syndrome virus (WSSV) in Indian farmed frozen shrimp products and testing for viability through bio-inoculation studies. J Aquacult Res Dev 1:102

Rodríguez J, Bayot B, Amano Y, Panchana F, De BI, Alday V (2003) White spot syndrome virus infection in cultured Penaeus vannamei (Boone) in Ecuador with emphasis on histopathology and ultrastructure. J Fish Dis 26:439-450

Rosenberry B (2001) World shrimp farming 2000. Shrimp News International, San Diego, CA

* Sahul Hameed AS, Anilkumar M, Raj MLS, Jayaraman K (1998) Studies on the pathogenicity of systemic ectodermal and mesodermal baculovirus (SEMBV) and its detection in shrimps by immunological methods. Aquaculture 160:31-45

Sahul Hameed AS, Charles MX, Anilkumar M (2000) Tolerance of Macrobrachium rosenbergii to white spot syndrome virus. Aquaculture 183:207-213

Sahul Hameed AS, Murthi BLM, Rasheed M (2002) An investigation of Artemia, as a possible vector for white spot syndrome virus (WSSV) transmission to Penaeus indicus. Aquaculture 204:1-10 
Sahul Hameed AS, Balasubramanian G, Musthaq SS, Yoganandhan K (2003) Experimental infection of twenty species of Indian marine crabs with white spot syndrome virus (WSSV). Dis Aquat Org 57:157-161

Sánchez-Paz A (2010) White spot syndrome virus: an overview on an emergent concern. Vet Res 41:43

Sarathi M, Ishaq Ahmed VP, Venkatesan C, Balasubramanian G, Prabavathy J, Sahul Hameed AS (2007) Comparative study on immune response of Fenneropenaeus indicus to Vibrio alginolyticus and white spot syndrome virus. Aquaculture 271:8-20

Sarathi M, Nazeer BA, Ravi M, Venkatesan C, Senthil KB, Sahul Hameed AS (2008) Clearance of white spot syndrome virus (WSSV) and immunological changes in experimentally WSSV-injected Macrobrachium rosenbergii. Fish Shellfish Immunol 25:222-230

Satoh J, Nishizawa T, Yoshimizu M (2008) Protection against white spot syndrome virus (WSSV) infection in kuruma shrimp orally vaccinated with WSSV rVP26 and rVP28. Dis Aquat Org 82:89-96

Shi H, Yan X, Ruan L (2012) A novel JNK from Litopenaeus vannamei involved in white spot syndrome virus infection. Dev Comp Immunol 37:421-428

Söderhäll I (2013) Hematopoietic stem cell culture in crayfish as a model for studies of hemocyte differentiation and immunity. Cytotechnology 65:691-695

Sun YM, Li FH, Chi YH, Xiang JH (2013) Enhanced resistance of marine shrimp Exopalamon carincauda Holthuis to WSSV by injecting live VP28-recombinant bacteria. Acta Oceanol Sin 32:52-58

Syed Musthaq S, Sudhakaran R, Balasubramanian G, Sahul Hameed AS (2006) Experimental transmission and tissue tropism of white spot syndrome virus (WSSV) in two species of lobsters, Panulirus homarus and Panulirus ornatus. J Invertebr Pathol 93:75-80

Tang KFJ, Navarro SA, Pantoja CR, Aranguren FL, Lightner DV (2012) New genotypes of white spot syndrome virus (WSSV) and Taura syndrome virus (TSV) from the Kingdom of Saudi Arabia. Dis Aquat Org 99:179-185

Tang KFJ, Pantoja CR, Redman RM, Lightner DV (2013) A histological variant of white spot syndrome virus (WSSV) from the Kingdom of Saudi Arabia. J Invertebr Pathol 113:82-85

Tendencia EA, Verreth JA (2011) Temperature fluctuation, low salinity, water microflora: risk factors for WSSV outbreaks in Penaeus monodon. Isr J Aquacult Bamidgeh 63:548

* Vijayan KK, Balasubramanian CP, Jithendran KP, Alavandi SV, Santiago TC (2003) Histopathology of Y-organ in Indian white shrimp Fenneropenaeus indicus, experimentally infected with white spot syndrome virus. Aquaculture 221:97-106

Walker PJ, Mohan CV (2009) Viral disease emergence in shrimp aquaculture: origins, impact and the effectiveness of health management strategies. Rev Aquacult 1:125-154

Editorial responsibility: Jeffrey Shields,

Gloucester Point, Virginia, USA
Wang CS, Tang KFJ, Kou GH, Chen SN (1997) Light and electron microscopic evidence of white spot disease in the giant tiger shrimp, Penaeus monodon (Fabricius), and the kuruma shrimp, Penaeus japonicus (Bate), cultured in taiwan. J Fish Dis 20:323-331

World Bank (2013) Fish to 2030: prospects for fisheries and aquaculture. World Bank, Washington, DC

*Yan DC, Dong SL, Huang J, Zhang JS (2007) White spot syndrome virus (WSSV) transmission from rotifer inoculum to crayfish. J Invertebr Pathol 94:144-148

* Yan DC, Huang J, Yang B, Sun HS, Wang YY, Liu X (2016) Competition of infectious hypodermal and haematopoietic necrosis virus (IHHNV) with white spot syndrome virus (WSSV) for binding to shrimp cellular membrane. J Fish Dis 39:1225-1229

Yin R, Guo YY, Wei ZL, Shi DJ, He PM, Jia R (2017) Pathogenicity of white-spot syndrome virus in Macrobrachium nipponensis via different infection routes. Chin J Biotechnol 33:1-11

* Yoganandhan K, Sathish S, Murugan V, Narayanan RB, Hameed ASS (2003) Screening the organs for early detection of white spot syndrome virus in Penaeus indicus, by histopathology and PCR techniques. Aquaculture 215:21-29

* Yuan J, Wang X, Gu Z, Zhang Y, Wang Z (2015) Activity and transcriptional responses of hepatopancreatic biotransformation and antioxidant enzymes in the oriental river prawn Macrobrachium nipponense exposed to microcystin-LR. Toxins (Basel) 7:4006-4022

* Yuan FH, Chen YG, Zhang ZZ, Yue HT, Bi HT (2016) Downregulation apoptosis signal-regulating kinase 1 gene reduced the Litopenaeus vannamei hemocyte apoptosis in WSSV infection. Fish Shellfish Immunol 50:109-116

* Yun JM, Kim BS, Hwang SM, Kim YB, Choi WB, Choi TJ (2014) Artificial infection of the native Korean freshwater prawn Macrobrachium nipponense (De Haan, 1849) (Decapoda, Palaemonidae) with white spot syndrome virus (WSSV). Crustaceana 87:866-880

Z Zeng Y, Lu C (2009) Identification of differentially expressed genes in haemocytes of the crayfish (Procambarus clarkii) infected with white spot syndrome virus by suppression subtractive hybridization and cDNA microarrays. Fish Shellfish Immunol 26:646-650

Zeng W, Zeng Y, Fei RM, Zeng LB, Wei KJ (2011) Analysis of variable genomic loci in white spot syndrome virus to predict its origins in Procambarus clarkii crayfish farmed in China. Dis Aquat Org 96:105-112

* Zhang Q, Xu T, Wan X, Liu S, Wang X, Li X, Huang J (2017) Prevalence and distribution of covert mortality nodavirus (CMNV) in cultured crustacean. Virus Res 233:113-119

* Zhu F, Quan H (2012) A new method for quantifying white spot syndrome virus: experimental challenge dose using TaqMan real-time PCR assay. J Virol Methods 184: $121-124$

Submitted: March 9, 2017; Accepted: August 4, 2017

Proofs received from author(s): October 2, 2017 